\title{
Do Chinese Corporations Take their Governance Practices Abroad? Evidence from Chinese Mining Subsidiaries in Australia
}

\author{
Xueli Huang *** \\ School of Management \\ RMIT University \\ 445 Swanston Street, Melbourne, VIC 3000, Australia \\ Tel: +61 399251648 \\ Fax: +61399255960 \\ Email: Charlie.huang@rmit.edu.au \\ Warren Staples \\ School of Management \\ RMIT University \\ 445 Swanston Street, Melbourne, VIC 3000, Australia \\ Tel: +61 399255964 \\ Fax: +61 399255960 \\ Email: Warren.staples@,rmit.edu.au
}

Xueli Huang ( $\mathrm{PhD}$, Monash University) is a senior lecturer at the School of Management, RMIT University, Australia. His research concentrates on the management of Chinese outward FDI, strategic management and innovation management. His publications have appeared in leading international journals, including Industrial Marketing Management, Asia Pacific Journal of Management, Journal of Small Business Management, and $R \& D$ Management. He is also co-author of two books on Chinese outward FDI and its management.

Warren Staples, $\mathrm{PhD}$, is a lecturer in management at RMIT University. His research interests are public management, public procurement, corporate governance and corporate social responsibility.

This is the author manuscript accepted for publication and has undergone full peer review but has not been through the copyediting, typesetting, pagination and proofreading process, which may lead to differences between this version and the Version of Record. Please cite this article as doi: $10.1002 /$ tie. 21918

This article is protected by copyright. All rights reserved. 


\section{Do Chinese Corporations Take their Governance Practices Abroad? Evidence from Chinese Mining Subsidiaries in Australia}

\section{Introduction}

China has recently emerged as an important source of global capital, ranked as one of the five largest countries in the world consecutively since 2009 in terms of outward foreign direct investment (FDI) (UNCTAD, 2015). Chinese MNCs had established nearly 30,000 subsidiaries in foreign countries by the end of 2014 (Ministry of Commerce, 2015). How Chinese multinational corporations (MNCs) govern their foreign subsidiaries is a common concern for many host countries (UNCTAD, 2010). Given the importance of corporations within developed and emerging economies, corporate governance has long been an important topic as it can have substantial impact on economic and social development (du Plessis, Hargovan, \& Bagaric, 2011).

This paper focuses on the roles of board of directors in Chinese-controlled subsidiaries in foreign countries. Existing corporate governance literature (Johnson, Ellstrand, \& Daily, 1996) suggests that boards of directors in the Western, Anglo-Saxon corporate governance model play three primary roles: control, service and resource dependence. Central to the Anglo-Saxon model and prevalent in the UK, US, Australia and other Anglo settings (Hill, 2010; Waring, 2008) is the unitary board composed of a majority of independent non-executive directors appointed to represent shareholder interests (Jeffers, 2005). The embedded normative goal of the corporation and hence its directors is to maximise the creation of shareholder value (Lazonik and O'Sullivan 2000; Donaldson 2012). In this context a key role of the board is to address principal-agent problems (Jensen and Meckling 1976) by aligning managers' interest with those of shareholders. Young et.al., (2001) explored the roles of boards of directors in overseas companies in East Asia (Hong Kong and Taiwan), and found that whilst these boards are established according to the formal mechanisms of the Western model, they function quite 
differently. Nevertheless, little research has been conducted on the corporate governance in foreign subsidiaries in general (Du, Deloof, \& Jorissen, 2015), and in Chinese controlled subsidiaries in foreign countries in particular. Given the rapid growth of Chinese outward FDI since 2008, it is important and urgent to establish a baseline understanding of corporate governance in Chinesecontrolled foreign subsidiaries before further improvement and strengthening can be made to their corporate governance practice.

Studying eight publicly listed Chinese-controlled subsidiaries operating in Australia, we explore the key roles played by the board of directors through in-depth interviews of the directors of these subsidiaries and their market analysts, and an analysis of information and contents of boards of directors published in the subsidiaries' annual reports. We address the following three questions: 1) how are the resource dependence, service and control functions fulfilled by boards of directors of Chinese controlled foreign subsidiaries; 2) in what ways do these functions differ from those welldocumented in the West? and 3) why do these differences exist from the institutional logics perspective?

Our paper contributes to the literature in three ways. Firstly, we provided a detailed description of the roles of boards of directors in eight Chinese controlled subsidiaries in Australia and offered a benchmark of the governance practice in such subsidiaries. Secondly we compare and contrast these functions with those well documented in Western countries, and explain these differences with multiple theoretical perspectives, including the institutional logic perspective (Thornton, Ocasio, \& Lounsbury, 2012), agency theory (Eisenhardt, 1989; Filatotchev \& Wright, 2011), resource dependency theory (Pfeffer \& Salancik, 1978). Thus, we respond to calls for building corporate governance theory with perspectives other than agency and resource dependence theories (Kumar \& Zattoni, 2015; Zattoni \& Van Ees, 2012) to analyse and explain the corporate governance practices in 
Chinese subsidiaries. Finally, examining the context of emerging MNCs and their corporate governance in their subsidiaries in the developed world provides a great setting for developing and refining corporate governance theory (Kostova, Marano, \& Tallman, 2016) as the corporate governance of Chinese subsidiaries abroad that has received little attention in the international business research to date.

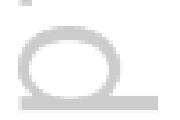

This paper is organised as follows. Firstly, we review literature on the key roles of boards of directors. Then we provide a brief description of institutional logic theory. After this, the historical development of corporate governance in China is outlined. This is followed by the research methods employed in this study. Finally, we present and discuss the findings and implications based on our case study of eight Chinese-controlled subsidiaries in Australia.

\section{Reviewing literature on the roles of boards of directors}

Extensive reviews of the roles of boards of directors have been covered in the literature (e.g., Johnson, et al., 1996; Zahra \& Pearce II, 1989). This section provides a brief description of the three broad categories of roles played by boards of directors.

The role of boards of directors has been a central topic in corporate governance scholarship (Hillman \& Dalziel, 2003; Kumar \& Zattoni, 2013), which has been predominantly examined from two theoretical perspectives: agency theory and resource dependence theory (Du, Deloof, \& Jorissen, 2011; Johnson, et al., 1996; Zahra \& Pearce II, 1989), although other theories, such as stewardship theory (Davis, Schoorman, \& Donaldson, 1997) and power theory (Jensen \& Werner, 1988), have also been utilised in the corporate governance literature. These two main theoretical perspectives deal with the 
control role of a board of directors over management and the service and resource dependence roles provided by the board to the $\mathrm{CEO}$ and the focal firm. These two theories are also very relevant in analysing corporate governance in foreign subsidiaries (Du, et al., 2011). Although boards of directors can play a wide variety of roles (Brennan, 2006), Johnson et al., (1996) summarised these roles into three broadly defined functions: control, services and resource dependence based on their extensive review of corporate governance literature. The control role refers to the directors' fiduciary responsibilities as the proxy of shareholders to monitor managers for ensuring managers' behavior is aligned with the shareholders' interest. While the service role describes the involvement of directors in initiating and developing strategy in the corporation and advice offered by directors to CEO and senior managers for operational and administrative issues (Johnson, et al., 1996), the resource dependence role views directors as a key channel to facilitate the access to critical resources for the organization's performance (Johnson, et al., 1996). These three roles have been widely accepted as a set of standard roles performed by boards of directors (Young, et al., 2001).

\section{Control}

The control role of boards of directors covers both monitoring and controlling (Johnson, et al., 1996). Effectively monitoring and controlling management is the central element of agency theory and probably the most widely examined role of the boards of directors in the literature (Hillman \& Dalziel, 2003). Garg (2013) defines monitoring as "the activities of the board and its individual directors that track the significant behaviours of executives, the outcomes of their actions, and the performance of the venture in order to ensure that corrective action is taken as needed" (p.90).

Boards of directors have a fiduciary responsibility to monitor management and control its behaviour as they are legal representatives of shareholders (Van den Berghe \& Levrau, 2004). Agency theory views the boards of directors as the primary internal mechanism for controlling managers' opportunistic behaviour. Boards exercise their monitoring and controlling function over CEOs 
through a wide variety of mechanisms, including the appointment of senior managers, altering incentive structures, and in extreme cases, dismissal (Kiel \& Nicholson, 2005; Monks \& Minnow, 2008).

Three broad types of control mechanisms can be performed by the boards of directors: outcome control, behavioural control and cultural control (Du, et al., 2011). While outcome control monitors and evaluates the performance of the organisation, behavioural control monitors its managerial behaviour. These two types of control are explicit and formal control mechanisms. In contrast, cultural control is an implicit and informal control mechanism and built on shared value, norms, and trust between the board and management (Ouchi, 1980), and is widely used in Chinese MNCs and their foreign subsidiaries (Chatzkel \& $\mathrm{Ng}$, 2013). However, cultural control can be expensive as it requires socialisation and continuous allegiance (Du, et al., 2011).

\section{Service}

Boards of directors can serve as a source of advice and counsel for a CEO as they may have relevant executive experience and functional expertise (Daily, Dalton, \& Cannella Jr, 2003; Krause, Semadeni, \& Cannella, 2013). Therefore, they can also provide advice to a CEO and senior executives on administrative and managerial issues and be actively involved in the organisation's strategy development process (Johnson, et al., 1996). Thus, boards of directors participation in the organisation's strategy formation is a crucial service they can provide to the focal firm. Directors' advisory role can dominate their board activities. However, whether boards of directors offer advice to the CEO can depend on their expertise and experience. Moreover, shared values, linguistic skills, and social ties between the $\mathrm{CEO}$ and the boards of directors can facilitate such knowledge transfers and service provision (Bengoa \& Kaufmann, 2016; Peltokorpi \& Vaara, 2014; Welch \& Welch, 2008) as directors may feel more comfortable in providing advice to the CEO (Westphal, 1999). 


\section{Resource dependence}

Resource dependence can be regarded as the external function of the board. From the resource dependence perspective (Pfeffer \& Salancik, 1978), boards of directors can be an important source of resources to the firm (Hillman \& Dalziel, 2003). With their "relational capital" (Hillman \& Dalziel, 2003, p.387) through their appointments in financial institutions or interlocking directorates with other organisations, boards of director can link the organisations to critical resources, such as finance, supplies, and markets in the environment or value networks through their connections with other organisations (Young, et al., 2001). They can also be an important boundary spanner and provide CEOs with relevant and timely information (Zahra \& Pearce II, 1989). In this way, boards act as a bridge for competencies and a conduit for information flow between the company and its economic and political environments (Melkumov, 2009). Moreover, directors can also add social capital to the organisation through their prestige and social recognition, or "human capital" (Hillman \& Dalziel, 2003, p.387), thereby securing legitimacy for the organisation, particularly for newly established companies (Zahra \& Pearce II, 1989).

Board composition and characteristics have been widely used as two important variables in examining the roles of boards of directors (Johnson, et al., 1996; Zahra \& Pearce II, 1989) as both can substantially influence all three key roles of the boards of directors (Hillman \& Dalziel, 2003). However, most of these studies have concentrated on the relationship between board composition and board roles in the Western countries (Hillman \& Dalziel, 2003). There is an increasing recognition of the influence of institutions on the roles of boards of directors (Filatotchev, Jackson, \& Nakajima, 2013; Globerman, Peng, \& Shapiro, 2011). For example, Young et. al (2001) studied the corporate governance of publicly-listed companies in Hong Kong and Taiwan, and found that these boards have a "formal, mechanical structure" that are established based on the Western, Anglo-Saxon model, but their actual functions "depart from this model" (p.236). Nevertheless there is scant research on why 
boards of directors function differently, particularly by Asian MNC controlled subsidiaries operating in Western countries.

\section{Institutional logic theory}

Corporate governance has been considered as an institutional logic (Joseph, Ocasio, \& McDonnell, 2014; Martin, Farndale, Paauwe, \& Stiles, 2016; Tihanyi, Graffin, \& George, 2014). The duality of symbolic structure and actual functions of boards of directors can be explained from the institutional logic perspective (Thornton, et al., 2012). Conceptually, institutional logics can be defined as "a set of material practices and symbolic constructions, which constitutes its organising principles" (Friedland \& Alford, 1991, p.248). Thornton and Ocasio (1999) view institutional logics as "the socially constructed, historical pattern of material practices, assumptions, values, beliefs, and rules." (p.804) and emphasised its physical and cultural manifestation. Moreover, an institutional logic has its own principles, practices, and symbols that shape the context under which reasoning takes place and rationality is perceived. Therefore, an institutional logic represents a frame of references that condition the choices of actors (individuals and organisations) for sense-making, the vocabulary they use to motivate action, and their sense of self and identify under different institutional orders (Thornton, et al., 2012).

Principally the institutional logics perspective is characterised by 1) the duality of agency and structure, 2) institutions as material and symbolic, 3) institutions as historically contingent, and 4) institutions at multiple-levels of analysis (Thornton \& Ocasio, 2008; Thornton, et al., 2012). The first three principles are very relevant to the analysis of corporate governance in foreign subsidiaries as they offer a new theoretical perspective to understand why the boards of directors function in particular ways. Thus, the institutional logics theory has been increasingly applied to the business studies, such as corporate governance (Joseph, et al., 2014), human resource management (Martin, et 
al., 2016), corporate social responsibility (Blindheim, 2015), and corporate ethical decision-making and behaviour in the context of MNCs (Kostova, Roth, \& Dacin, 2008; Tan \& Wang, 2011). However, few studies have been conducted in the area of corporate governance of foreign subsidiaries.

From the institutional logics perspective, corporate governance can be substantially different between Australian and Chinese corporations partly due to their national culture and history. While it is well understood that there are substantial differences in political institutions between Australia and China, their national culture also differs substantially. Australia was a colony of the UK from 1788 to 1901 when it became an independent nation and a constitutional monarchy. The 100 plus years of British colonisation has had an overwhelming effect on Australian culture as it "imported ...culture, by a system of one-way traffic" (Stephensen, 1936, Section 4). Based on the five national culture dimensions developed by Hofstede (2001), Australia's scores are very close to those of the UK, except long-term orientation, but substantially differ from those of China (Table 1). Compared with China, Australia scores much higher in individualism, but much lower in both long-term orientation and power difference. National culture can substantially affect corporate governance in the areas of board composition and leadership structure (Li \& Harrison, 2008), and pose challenges for Chinesecontrolled subsidiaries to manage their business abroad (Sun, Zhang \& Chen, 2013). Nevertheless, not enough research has been devoted to study how national culture influence corporate governance in foreign subsidiaries, particularly those from China and operating in developed countries, such as Australia.

(Insert Table 1 about here)

\section{The Development of Corporate Governance in China and its Characteristics}


Corporate governance in Chinese companies has been under transition since 1949 when the Communist Party of China (CPC) took control. Since then, corporate governance in China has undergone four stages of development (Kang, Shi, \& Brown, 2008).

The first stage (1949-83) is the pre-reform era when state-owned enterprises (SOEs) were overwhelmingly dominant in the national economy. The state was the owner of all Chinese commercial organizations and extensively and directly involved in their operations from supplying, manufacturing, distribution to consumption. Strictly speaking, all Chinese commercial entities became corporatized as they were owned by Chinese citizens as public shareholders. The most important intervention used by the government was the appointment of party secretaries and senior managers to prominent roles within the company. To wit, business organizations were treated as cost centres or working units (the danwei) of the government.

The second stage of development began in October 1984 when the Central Committee of the CPC announced the decision to reform its national enterprise system (Tenev \& Zhang, 2002) and explicitly ordered the separation of the government from enterprise operations. Consequently, the Chinese government gradually delegated responsibilities from bureaucrats or government agencies to SOE managers by introducing performance incentives, price liberalization, profit retention, and contracting responsibilities to managers (Tenev \& Zhang, 2002). However, no fundamental changes were made to the ownership structures of SOEs, although China started experimenting with ownership reform with eleven SOEs becoming shareholding enterprises in 1986 (Kang, et al., 2008). Nevertheless, the structure of corporate governance in China remained largely unchanged during this period.

The third stage of corporate governance development in China began in 1993 when the Third Plenary Session of the 14th Party Congress issued the Decision on Issues Concerning the Establishment of a Socialist Market Economic Structure (Y. Huang, 2001). Subsequently, the Standing Committee of the 
People's Congress of China issued its Company Law that states the primary goal of corporate practice is to maximise its owners' interests. China formally introduced the concept of the corporation through importing the Western corporate governance model (Roche, 2006, p.36). This reform was a crucial part of China's effort to create a "modern enterprise system" and diversify its reliance on state ownership. This triggered a new wave of enterprise reform in China focusing on the corporatization and ownership diversification of Chinese SOEs. These market-oriented reforms led to many large and medium SOEs corporatizing themselves and most small SOEs being bought out by their managers, employees, or individuals, often dominated by insider managers as the Chinese government wanted these enterprises to retain their employees. As a result, many larger SOEs have been publicly listed, often through carving out part of the corporation, and becoming listed on domestic or international stock exchanges, in part to raise money from the public and foreign investors. Listing Chinese SOEs in the international stock exchanges is very important to the improvement of corporate governance and the further development of Chinese stock exchanges. The stock exchanges in international developed markets, such as Hong Kong and the USA, are able to provide a large scale of equity capital to financially support the future growth of the Chinese firms listed (Ding et al., 2010, Saudagaran, 1988). More importantly, they have well developed and stringent legal and monitoring environment, corporate governance, and auditing and accounting standards (Cheung et al., 2007, Coffee Jr, 2002). Through listing shares in these developed international markets, such as Honk Kong, and the USA, Chinese SOEs could leverage on the international markets' better corporate governance practice, legal standards, and accounting requirement through their internal diffusion of corporate governance practices (Sun and Tobin, 2005). This was crucial at that time when the corporate governance in Chinese firms was very weak (Chen et al., 2006) and could also further improve the credibility and prestige of Chinese SOEs among investors due to the "bonding" effect (Coffee Jr, 2002) as many of them were subsequently cross-listed in the Chinese stock exchanges. Ultimately all 
these could help Chinese government establish a modern corporate system in China (Sun et al., 2013). Nevertheless, structurally, the Company Law promulgated in November 1993 introduced many of the corporate governance mechanisms of the Anglo-Saxon business model including the establishment of boards of directors in large corporations, and the role of external auditing. China also established two stock exchanges in 1990 and 1991, and the China Securities Regulatory Commission in October 1992. Institutional investors, both international and domestic, have gradually been encouraged to invest in the Chinese stock exchanges.

The National People's Congress passed a revision of the Company Law in October 2005, marking the start of the fourth stage of corporate governance development in China. It formalised the requirement for independent non-executive directors to be part of the board, clarified the fiduciary responsibilities of directors, role of the board and management, as well as protection of the rights of minority shareholders. The initiatives have further improved the corporate governance model structurally in China.

Although the Chinese government adopted Western models of corporate governance, restructured the administration and structure of SOEs (Rowley \& Warner, 2013), and delegated many responsibilities to business organizations, practically the corporate governance of Chinese corporations is still quite different from that of developed countries (Tam \& Yu, 2011). This is primarily due to its "socialist principles" (Ntongho, 2016) and Confucian values (Chatzkel \& Ng, 2013). The main reasons behind such differences are as follows:

There is "loose coupling" (Meyer \& Rowan, 1977) between company law and corporate governance practices as the Chinese government is still the sole or substantial owners of many large Chinese commercial organizations, and heavily involved in business activities at the organizational level, including the appointment of board of directors and senior managers. As Tenev and Zhang (2002) 
concluded in their studies of corporate governance in China: "ownership diversification and corporatization have had only a limited impact on corporate behaviour". Corporate governance in Chinese corporations can be described as a control-based model with control exercised by the major controlling shareholder, often the Chinese government (Liu, 2006). This model is characterized by 1) the controlling shareholders (often the state) employing all feasible internal governance mechanisms to tightly control the listed companies (Hu \& Cui, 2014), and 2) the presence of a management friendly board (Liu, 2006).

Weak corporate governance practices in China have also been pointed out as the major cause of recent corporate scandals and poor corporate performance in Chinese companies. These include corruption, stock market manipulation, tax cheating, fraudulent dealing, the plundering of state assets, and the lack protection of minority shareholders' rights (Tam, 2002). Moreover, the interests of minority shareholders may not be protected due to the ownership concentration in Chinese companies (Yang, Chi, \& Young, 2011; Young, Peng, Ahlstrom, Bruton, \& Jiang, 2008). This is referred to as "principal - principal" conflict where conflicts between controlling shareholders and minority shareholders result from concentrated ownership, business group structures and weak legal protection of minority shareholders (Dharwadkar, George, \& Brandes, 2000; Young, et al., 2008). These principal-principal problems are often characterised by the lack of a sufficient number of independent non-executive directors on the board in Chinese companies (Liao, Young, \& Sun, 2009; Tan et al., 2007).

Further exacerbating the nature of principal-principal conflict is the prevalence of pyramidal ownership structures and non-tradable shares in the Chinese equity market which means controlling shareholders appropriate money from listed companies (Chen, Firth, \& Xu, 2009; Yang, et al., 2011). The application of internal mechanisms of corporate governance and pyramidal business structures with the perception of principal-principal conflict combined with business scandal have generated a 
perception among Chinese business executives, bureaucrats and the public that corporate governance in China is a weak corporate control mechanism. However, this situation is gradually changing due to reform introduced in 2005. Young et al (2008) focus on these principal-principal issues particularly in the case of family ownership and generational transition, but provide little insight into the issues affecting minority shareholders in publicly listed companies where the major shareholders are Chinese SOEs.

In highly dispersed ownership corporate governance environments, such as those in the UK, USA and Australia, the focus is on reducing principal-agent problems. Incentives frequently take the form of performance based remuneration using bonuses to align the interests of agents with principals, and/or stock ownership to give agents ownership rights (Boyd, 1994; Lee, 2002). However, the concentrated ownership structure in China means that the central agency problem is the exploitation of minority interests by controlling block holders, implying that managers are usually appointed by controlling shareholders to represent their interests (Yang, et al., 2011).

\section{Methods}

This study explores the roles of boards of directors in Chinese-controlled subsidiaries in Australia. Although there are subsidiaries controlled by overseas Chinese companies, such as those from Hong Kong and Taiwan, we only focused on those Australia's subsidiaries controlled ultimately by Chinese parent corporations in this study. Our research adopted a multiple case study approach (Yin, 2014) through in-depth interviews and secondary data analysis. The foci are on the understanding of corporate governance in Chinese controlled subsidiaries overseas and on why certain differences in corporate practices exist. This study is also a response to the recent calls for more context-specific research (Galvin, 2014; Tsui, 2007). We have used the following four criteria in selecting a stratified sample of cases (Flyvbjerg, 2006): 1) Chinese investment greater than A $\$ 10$ million as this is 
considered as a major investment decision according to the Australian government investment policy (Foreign Investment Review Board, 2014); 2) the Chinese share in their foreign entity is more than 40 per cent (an effective control majority) (DePamphilis, 2010) in order to focus solely on the corporate governance practices within Chinese controlled subsidiaries; 3) their major business operation is in the Australian mining industry as over 60 per cent of the overall Chinese OFDI in Australia by the end of 2014 (Ministry of Commerce, 2015); and 4) the subsidiary is publicly listed on the Australian Securities Exchange (ASX) in order to study a sample with the presence of very similar Australian institutional pressures and to enable access to their corporate governance disclosures and reports. Eight Chinese subsidiaries met these criteria and thus were selected. These Chinese subsidiaries held interests in gold, iron ore, non-ferrous and base metals, coal and uranium. Table 2 shows the characteristics of the parent companies and their Australian subsidiary.

(Insert Table 2 about here)

As all eight companies are listed on the ASX, detailed information about the board composition (proportion of independent and insider directors and size) and their characteristics (e.g., directors' experience, functional expertise, and education) were available from publicly available annual reports and their websites. Moreover, the website of their parent company was also studied for information about their ownership and major operations.

To further explore the roles of boards of directors in Chinese-controlled subsidiaries in Australia, we conducted seven interviews with three insider directors (including one insider chairman) (coded as D1- D3), two independent directors (IP 1-2), two consultants (C1 -2), and four market analysts (MA14) on the subsidiaries studied. These interviews were to investigate how the boards are operating and why independent directors were recruited. These interviews ranged from thirty-five minutes to twoand-half hours. Recording of interview was permitted by seven interviewees. The recorded 
interviews were then transcribed verbatim. In other four cases, notes were taken during the interviews. A summary was prepared for each of these interviews within two days of the interview conducted.

We developed a broad coding scheme based on the three key board roles discussed by Johnson et al., (1996) and used it to code the contents of the eight companies' annual reports in 2014 and their web site for the three roles of boards of directors. More specifically, we examined board composition and characteristics, including the proportion of independent directors and insider directors, their experience and functional expertise, directors' interlock, number of board meetings, and the nationality of chairperson and CEOs appointed. In addition, our interview analyses focused on the board behaviours and the reasons for such behaviour to complement the results of our content analyses.

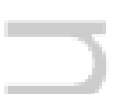

\section{Findings}

\section{Control}

Control is the primary function of the boards in the Chinese-controlled subsidiaries that strongly prefer direct control through the boards of directors. Table 3 presents the board composition and size of the eight Chinese-controlled subsidiaries studied, and the nationality of board chairpersons and CEOs appointed. It shows that six (except S2 and S5) out of eight subsidiaries have a majority of Chinese insider directors on the board with 24 out of 48 being directors from inside the parent corporation. For those two subsidiaries without a majority of insider directors, S2 held 46 per cent of the subsidiary's shares. Thus, it is not surprising that the percentage of insider directors from their parent company was less than 50 per cent. At the time of the data collection, S5 had just increased its shareholding from 49 per cent to 89 per cent. Thus, the number of insider directors may have not been increased accordingly. 
It is interesting to note that where two Chinese-controlled subsidiaries have not had a majority of Chinese insider directors, one has appointed an insider CEO and another one appointed a CEO of Chinese origin. This can reduce the need for formal monitoring and control exerted by the board and instead rely on cultural control (Du et al., 2011). Moreover, seven (except S2) of the Chinese parent corporation have appointed insider chairmen to their Australian subsidiary. Therefore, the "control model" of corporate governance prevalent in China has been adopted in Australia.

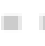

\section{(Insert Table 3 about here)}

Our interviewees highlight the dominant preference for control by ownership. This was vividly expressed by a chairperson who was the president of the parent corporation as he expressed: "[W]e are a large Chinese SOE. If we don't have control over the (foreign) companies invested, why should we be there?" (D1)

Similarly, a senior consultant and manager at a major international accounting firm, specialising in Chinese investment in Australia, said:

"Chinese investors like having a majority of ownership when they invest in Australia. Chinese investors think if they have a controlling stake in the company invested, they are the decision-makers for everything." (C1)

This control role of the board was echoed by one of the independent directors interviewed, who stated that:

'Chinese-controlled subsidiaries in Australia tend to have a 'Chinese colour' in their corporate governance. That is, they strongly believe in 'money talk' as they are the major shareholders" (IP1).

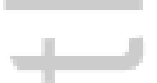

It is interesting to find that one (S2) of the two subsidiaries that did not have a majority of insider directors has appointed independent directors with Chinese origin. While asking about the criteria for appointing directors, one independent director from that subsidiary commented: 
"Trust is very important to Chinese controlled subsidiaries in appointing independent directors. Cultural understanding and language are two key factors in building up trust. Thus, Chinese controlled subsidiaries tend to appoint independent directors who can speak both Mandarin and English for easy communications." (IP1)

Similarly, another insider director commented on the importance of trust and understanding in selecting independent directors

"Our parent corporation is a Chinese SOE that is under the administration of SASAC [The State-owned Assets Supervision and Administration Commission]. According to "SASAC's regulations, all subsidiaries have to comply with the reporting requirements by SASAC. Some of these requirements are unique to SOEs. Thus, when we appoint independent directors, we would like to have someone who not only has expertise, but also can understand the management of Chinese SOEs." (D2)

The importance of trust in appointing directors was also stressed by one market analyst during our interview stating: "They [Chinese corporations] also want to have a sense of control, because there is still not a trust here [in Australia]. They [Chinese corporations] need time to build up the trust." (MA1)

It is strongly evidenced that Chinese corporations prefer direct control over their foreign subsidiaries through the board. This control logic has been implemented through appointing 1) a majority of insider directors, or 2) insiders and those have a good understanding of Chinese culture and could speak both Mandarin and English, typically of Chinese-origin, to take up a majority of the board seats. While the former can exert the direct control from the board, the latter one aims to do this indirectly through the appointment of a friendly board and cultural control (Du et al., 2011).

Monitoring is an important function of effective control by the board. In the Chinese-controlled subsidiaries studied, this has been done by appointing executive directors from the parent corporation to senior managerial positions of their subsidiary. Seven out of eight Chinese-controlled subsidiaries have appointed at least one inside executive director, while the subsidiary that did not appoint an inside executive director has a CEO of Chinese origin. These insider directors not only have an operational role within the subsidiary, but also collect information about the subsidiary's operations 
and monitor how strategic decisions made by the board is implemented. Such information can be communicated to other insider directors for decision-making. One inside executive director described his role in the subsidiary:

"I am the only one insider executive director in the company [subsidiary], and responsible for liaising all important issues with China [the Chinese parent corporation], such as financing, procurement and sales in China. However, I am also responsible for collecting and preparing all information for the parent corporation for the [subsidiary's] board meetings".

This was also echoed by one of the market analysists (MA4) interviewed. When commenting on the corporate governance at one of the subsidiaries studied, he noted:

"They [the Chinese parent corporation] have one insider on the board. But he is largely an operational officer, and largely for [collecting] operational knowledge and local knowledge”. (MA4)

\section{Service}

The service role played by the boards has been considered as being important in corporate governance literature (Hillman \& Dalziel, 2003). Boards of directors can advise CEOs for better managing the company and assist them for developing strategy for the organisation. Table 4 shows the experience and functional background of both insider and independent directors. There are several findings in Table 4. First, Chinese-controlled subsidiaries have appointed directors with rich expertise and experience in several functional areas. These expertise and experience include mining operations, geology and exploration, auditing, risk management, government and stakeholder relations, safety, and legal services. These functions are critical to the companies' operations and development. For example, five out of eight subsidiaries have appointed at least one director with geology knowledge given the critical importance of such knowledge to mining operations, particularly those at the exploration stage. Moreover, the experience and expertise of those independent directors appointed to these Chinese-controlled subsidiaries are also often complementary to those of the parent corporations, 
such as occupational health and safety, auditing and accounting, and host country's stakeholder relations.

(Insert Table 4 about here)

Asked what Chinese-controlled subsidiaries look for when recruiting independent directors, one independent director replied:

"I have a very good track record in providing legal services to Chinese companies, particularly those in the mining industry. I have played a significant role in advising the CEOs in corporate law and labour law. In general, Chinese companies lack talents in international law." (IP1)

Similarly, another independent director (IP2) said he was appointed as independent director primarily due to his managerial experience in the mining industry.

One market analysist (MA2) pointed out the lack of expertise for Chinese parent corporations to manage their Australian operations:

They [Chinese parent corporations] want to run the operation themselves, but the problem is that they don't have the expertise themselves... they can only gradually acquire the expertise to run the operation themselves... the board is there for knowledge. (MA2)

One insider director also stressed the importance of services in appointing directors in the Chinesecontrolled subsidiary he worked for as he described how the subsidiary nominates directors:

"We are looking for independent directors with expertise and experience. If you look at all independent directors in our board, all of them have over 20 years of experience. It may not be so important to have a majority of insider directors for control. If the parent corporation's decision is reasonable, it would get the support from the independent directors. Otherwise, it would not". (D2) 
However, service may only play a secondary role in appointing directors when compared with the role of control. For example, when asked if all independent directors are appointed based on their services to the board, one independent director stated:

"Some independent directors are appointed as they are professional directors. However, they have little expertise and experience to advise the CEO and may not be acceptable by larger [Australian] companies... It depends on what the board of directors the subsidiary would like to have." (IP1)

Secondly, insider directors are appointed often based on their positions at the parent corporation, rather on their expertise because the parent company collectively plays a major role in offering services to the companies they invested. The key board decisions are often made by the parent company before the board meetings as one interviewee stated:

"It really doesn't matter who is sitting on the board [of the subsidiary] because the headquarters of our parent corporation have made the important decisions [for the subsidiary] before the board meetings." (D3)

The parent corporations may also use the expertise and knowledge from its other foreign subsidiaries to assist decision-making of the board. For example, executives of other subsidiaries of the same parent corporation in Australia have been used to advise the CEO of its subsidiary studied, as one interviewee said:

"The parent corporation has another subsidiary in Australia. The CEO in that subsidiary has completed the courses with the Australian Institute of Company Directors. She has a good understanding of how an Australian company should be governed and offered her advice to the CEO in this subsidiary". (C2)

The number of board meetings held is an important indicator for the extent the board is involved in the strategic decision-making. Four of eight subsidiaries had 10 and more board meetings in 2014 while the other four subsidiaries had six or less board meetings. This difference in the number of board meetings may partly depend on whether the CEO is an insider or outsider. Where the CEO or 
managing director is an insider, the number of board meeting is less than those with an outsider. This suggests that the high level of trust placed by the board on the CEO reduces the need to monitor and exert formal strategic control by the board to the subsidiary.

Further highlighting the appointment of directors by parent corporations for control rather than service, one Chinese insider director commented on the role of the board meeting in making strategic decisions for the subsidiary:

"We had nine board meetings the first year we acquired the subsidiary [where its CEO is an Australian professional manager]. Thus, most strategic decisions were made through the board meetings. Moreover, the President of our parent corporation took the position of the chairman of the board, further strengthening the role of strategic decision-making at the board level" (D2)

While such decision-making process may heavily draw knowledge and competences from the parent corporation, it can cause the principal-principal conflict (Young, et al., 2008) between the major and minor shareholders as the interest of minor shareholders may not be protected.

\section{Resource dependence}

The third important role played by the boards of directors is to help secure critical resources. Boards can play an important role in managing resource dependency (Slancik 1978) through several mechanisms as indicated by board size, the proportion of independent directors, and pattern of interlocks between organisations representing different sectors (Johnson, et al., 1996). Table 5 presents the board size and interlocks of independent directors in these eight Chinese-controlled subsidiaries.

(Insert Table 5 about here)

With regards to board size, the number of directors for these eight Chinese-controlled subsidiaries ranged from three to eleven with an average of six. Except S1 which has a large operation, other 
Chinese-controlled subsidiaries were found to have small board sizes, indicating that access to critical resources is not an important role for the board in these subsidiaries.

The average proportion of independent directors in the subsidiaries studied is $39.6 \%$. This is quite low compared with $68.5 \%$ of the ASX 300 in 2010 (Williams, Bingham, \& Shimeld, 2015). Moreover, two out of the eight subsidiaries studied had not appointed any independent directors to their board. This strongly indicates the weak perception of Chinese parent corporations on the importance of independent directors in facilitating access to critical resources.

Regarding the interlocking sectors for the independent directors, the mining industry was dominant and observed in all five Chinese-controlled subsidiaries with independent directors. A total of thirteen out of nineteen independent directors have inter-locking directorship. Director interlocks with miningrelated services, such as mining engineering and transportation, are also observed in two subsidiaries. An examination of the directors' interlocks in these eight Chinese-controlled subsidiaries reveals that all interlocks are with Australian companies, suggesting the local knowledge and information, rather than international ones, are mainly sought by these Chinese-controlled subsidiaries in appointing independent directors. Moreover, none of the subsidiaries studied appoints directors from banks or financial organisations. This is not surprising as Chinese corporations usually get financing from Chinese banks for their investment overseas. Financing international investment with low interest and subsidy from governments is common for Chinese corporations, and has been considered as a comparative advantage for them (Buckley, Cross, Tan, Xin, \& Voss, 2008). These findings suggest that independent directors are not considered by these Chinese-controlled subsidiaries important for accessing financial resources.

Social capital, rather than financial capital, is important in appointing directors in some Chinesecontrolled subsidiaries for managing government and stakeholder relations. For example, S1, a large 
subsidiary operating in the coal industry, has appointed a former high-ranking government diplomat to the board who had over 30 year experience working in a government department, while S6, another Chinese controlled subsidiary operating in the gold industry, employed a professional director who "has extensive executive leadership skills and wide experience in communicating with capital markets, shareholders and the media" (the subsidiary's web site). One interviewee commented on this:

"Chinese companies tend to consider board of directors as government officials and -appoint directors politically. Although the director [appointed by S1] has no legal, technical and managerial expertise, he was a high-ranking ex-government official and may help the subsidiary look good." (C2)

Business network, or "relational capital" (Hillman \& Dalziel, 2003), is another resource in appointing independent directors by Chinese-controlled subsidiaries in Australia. One independent director expressed:

"Although I am sitting on the board, I perform my duties as an independent director. I cannot offer legal opinion to the board. I can do this only as a legal practitioner if the subsidiary would like to do business with me through my law firm." (IP1)

Similarly, one market analysist (MA1) interviewed expressed:

"The connections and expertise [of independent directors] are most important ...the connections in the sense that they (Chinese controlled subsidiaries) wanted to bring on board some senior people who have a good reputation in industry".

\section{Discussion}

This study explored the board functions of Chinese-controlled subsidiaries in Australia. We focused on the three major roles performed by the board (Johnson, et al., 1996): control, service and resource dependence, in eight Chinese-controlled subsidiaries listed in the ASX. Table 6 summaries the board functions, their key mechanisms, and rationale for the differences in these functions.

(Insert Table 6 about here)

Table 6 reveals several characteristics of corporate governance of Chinese-controlled subsidiaries in Australia. First, control has been found as the primary and dominated function performed by the 
board through appointing a majority of board or establishing a friendly board via recruiting those independent directors who have a good cultural understanding or can speak Mandarin, while monitoring is performed by appointing insider CEO or insider executive directors. This is similar to the findings of Hu and Tam (2012) in their studies of corporate governance in China. The boards are also heavily involved in strategic decisions through board meetings. This is different from what found in the overseas companies listed in the Hong Kong Stock Exchange (Young, et al., 2001) where controlling and monitoring are not pronounced. Part of the reason for this difference is that the parent corporations in our study is the controlling shareholders who has a high stake in the subsidiary and thus has power to exercise its control over the subsidiary's management. Therefore, the controlling and monitoring role of the board is very important from the parent corporation perspective and dominant in this study.

Service to the CEO by the board, although important in the Western corporate governance model, is not regarded as important as control in Chinese-controlled subsidiaries for several reasons. First, most strategic decisions have been made by the parent corporation through its insider directors on the board. This often leaves operational issues to the subsidiary's CEO. Second, most of directors in the Chinese-controlled subsidiaries are insiders who often hold senior managerial position in the parent corporation and reside in China. They often lack of language skills in communicating directly with those locally appointed CEO. Thus, the social ties between the directors and CEO is not strong. Third, their Chinese experience may not be relevant to the management of their subsidiary in Australia. Nevertheless, some Chinese corporations have increasingly recognised the importance of directors' service to the subsidiary's CEO and recruited independent directors with rich managerial experience and functional expertise. 
Securing crucial resources, particularly financial resources and information, has been considered as an important role of the board (Johnson, et al., 1996). However, it is not dominant in the Chinesecontrolled subsidiaries studied due to their control-oriented logic of corporate governance. We found that the boards in the Chinese-controlled subsidiaries can play a crucial role in securing social capital and legitimacy through appointing high profiled ex-government officials or experienced executives in stakeholder management. Given the negative sentiment and contentious political debate in Australia about Chinese investment (Huang \& Austin, 2011), securing social capital and legitimacy in host countries is critical to the success of Chinese investment abroad, particularly for those Chinese corporations operating in the environmentally or socially sensitive industries, such as mining and infrastructure industries (Gifford, Kestler, \& Anand, 2010; Kostova \& Zaheer, 1999).

Overall our findings suggest that the role the boards of directors play in Chinese-controlled subsidiaries in Australia is primarily monitoring, control and oversight of the parent corporation's investment (Capezio, Cui, Hu, \& Shields, 2014), rather than adding value to the operations of the subsidiary in the form of professional competence and business connections to the board (Yoo \& Kim, 2012). The governance model adopted suggests that there is a strong influence of institutional logic on the structure and practices of corporate governance in these subsidiaries. The broad roles of corporate governance in these Chinese-controlled subsidiaries are structurally similar to that of other companies listed in the ASX. However the practices of boards of directors are very different from others as they are heavily influenced by the culturally embedded and historically dependent institution logics of home country. The parent corporations still adopted a control-oriented model in governing their foreign subsidiaries through using several key mechanisms, including the appointment of insider directors, establishment of a friendly board, appointment of insider CEO or insider executive director(s). This can result in principal-principal problems (Young, et al., 2008), and may be detrimental to the subsidiary's financial performance as the role of service to CEO and access to 
critical resources are often sacrificed for the control motives. These characteristics of board roles need to be understood from a comparative view of national institutions (Filatotchev, et al., 2013) and have several implications for the improvement of corporate governance in Chinese controlled subsidiaries abroad in the future.

\section{Conclusion and implication}

This study explores the roles played by the boards of directors in Chinese-controlled subsidiaries in Australia and explains why these practices differ from those well documented in the Western model. To do so, we have conducted case studies of eight Chinese-controlled subsidiaries operating in the Australian mining industry through conducting eleven in-depth interviews with directors, consultants and market analysts, and content-analysis of their annual reports and websites. Several important conclusions can be drawn based on the findings.

The first conclusion is that the roles played by boards of directors in Chinese -controlled subsidiaries are similar in structure to those widely reported in Western, Anglo-Saxon model, but different in practice. Although the boards of directors were established based on Australia's regulatory requirements such as the separation of board chairperson and CEO, appointment of independent directors to the boards and subcommittees, boards' practices deviate substantially. The dominant role played by these boards is control over the management for the interest of parent corporation through the use of several mechanisms, including the appointment of insider directors and senior management.

Secondly, the boards of directors are considered as an important resource for information and enhancing business and government relations. Nevertheless, they play no role in assisting finance because a majority (13 out of 19) of independent directors are interlocking only within mining and 
mining-services industries, but having few ties with financing or banking industries. In addition, boards of directors are considered as a source of social capital for securing the subsidiary's legitimacy.

Thirdly, the service role of boards of directors is not pronounced, although its importance is increasingly recognised. The boards play a ceremonial role in making strategic decisions of the subsidiary as these decisions are often made by the parent corporation and then passed to the subsidiary's board through its insider directors. Moreover, boards provide only limited services to the $\mathrm{CEO}$ as most of the insider directors appointed lack experience in international management, while some outsider directors are appointed for control or are affiliated ones, rather than based on their experience and expertise.

The final conclusion is that the institutional logics perspective is useful in explaining the adoption of corporate governance practices in Chinese-controlled foreign subsidiaries. It has provided a new perspective for examining why some corporate governance practices in Chinese-controlled subsidiaries cannot be easily changed. It also offers new mechanisms through which corporate governance practices within Chinese-controlled subsidiaries can be changed, particularly through both material practices and symbolic values. By and large, Chinese-controlled subsidiaries have complied with the ASX's good corporate governance and best practice recommendations structurally symbolically, but not in practice. However, the practices of corporate governance in these subsidiaries still remain challenging due to the long-inherited cultural aspect of corporate governance among Chinese executives. Specifically, Chinese corporations apply the corporate governance model in China to their foreign subsidiaries, which is primarily control-oriented, particularly through ownership control. This is primarily due to China's dominant logic of state and managerial control, and partly to a high level of trust on agents in these key posts as valued by Chinese culture (Chatzkel $\& \mathrm{Ng}, 2013)$. The patterns of these corporate governance practices in Chinese-controlled foreign 
subsidiaries are therefore similar to that in China, reflecting the deep rootedness and stickiness of the corporate control logics from the dominant institutions in China.

Several implications can be suggested based on our findings. From the institutional logics perspective, the further improvement of roles of boards of directors in Chinese-controlled subsidiaries in Australia can be made in the material practice of the boards, which is partly influenced by the institutional logics of corporate governance in China where the parent corporations are operating within. It is not expected that such a culturally-embedded and historically-dependent institutional logic can be changed overnight in China. Thus, the control-oriented corporate governance would still be observed in Chinese-controlled foreign subsidiaries in the near future. Duty of loyalty and duty of care are the two major responsibilities for the board of directors (Monks \& Minnow, 2008). While the directors' loyalty to the major shareholder, in this case Chinese parent corporations, is important, the interests of minority shareholders should also be respected. Otherwise, there might be conflicts of interest arising between the major shareholder and minor shareholders, that is principal-principal conflicts (Renders \& Gaeremynck, 2012; Young, et al., 2008), which can depress the organizational value due to the 'corporate discount' placed by investors and thus increase financing costs to the subsidiary. The challenge for Chinese corporations is how to balance the roles of control and resource dependence, with aims to control and at the same time to have the boards fulfil a service role with adequate expertise, experience, and information for decision-making.

To address such a challenge Chinese corporations need to develop their human resources, particularly in the areas of international business and international legal systems. While the role of control for the boards of directors as the proxy of shareholders is important, the duty of care requires that directors have considerable information, experience, and knowledge to facilitate effective decision making and monitoring. This means that the importance in developing a pool of senior managers within Chinese 
corporations who are competent commercially, with cultural capabilities and linguistic skills, can be appointed as directors in their foreign subsidiaries.

Form a long-term perspective, Chinese corporations need to change the roles of boards of directors from the control-oriented to service-oriented in the future. This can avoid the risk of "governance failures" and contribute positively towards success of the Chinese investments abroad. Practically, this requires a right mix of types of directors (independent, insiders, and affiliated) on subsidiary boards. Increasing the proportion of independent directors with rich experience and expertise that complements insider directors can substantially contribute to the success of Chinese investment abroad.

\section{Limitations and future research}

Several limitations exist in this study. First, Chinese outward FDI is a relatively new phenomenon. Thus, the sample size in this research is limited by the small number of Chinese-controlled subsidiaries in the Australian mining industry. This study only focused on eight relatively large Chinese-controlled, and publicly listed subsidiaries in the Australian mining industry. Therefore, caution must be exerted in generalising the findings to other Chinese foreign subsidiaries in other settings, such as different country, industry, and in different ownership structures (e.g., public vs private). A comparative study (countries, industries, and ownership structures) can provide a more comprehensive picture on the roles of boards of directors in the Chinese-controlled subsidiaries overseas. Second, Chinese corporations are still learning from their international operations, including corporate governance. Thus, a longitudinal study on this topic has great potential to further illuminate changes in corporate governance practices within Chinese subsidiaries abroad. Finally, we collected qualitative data of corporate governance practices through both in depth interviews and 
publicly available sources. Future quantitative studies such as surveys of directors in Chinese

controlled foreign subsidiaries may provide a more comprehensive picture into how widespread these corporate governance practices are in Chinese subsidiaries.

\section{References}

Bengoa, D. S., \& Kaufmann, H. R. (2016). The Influence of Trust on the Trilogy of Knowledge Creation, Sharing, and Transfer. Thunderbird International Business Review, 58(3), 239-249.

Blindheim, B.-T. (2015). Institutional Models of Corporate Social Responsibility: A Proposed Refinement of the Explicit-Implicit Framework. Business \& Society, 54(1), 52-88.

Boyd, B. K. (1994). BOARD CONTROL AND CEO COMPENSATION. [Correction notice]. Strategic Management Journal, 15(5), 335-335.

Brennan, N. (2006). Boards of Directors and Firm Performance: is there an expectations gap? Corporate Governance: An International Review, 14(6), 577-593.

Buckley, P. J., Cross, A. R., Tan, H., Xin, L., \& Voss, H. (2008). Historic and Emergent Trends in Chinese Outward Direct Investment. Management International Review, 48(6), 715 - 748.

Capezio, A., Cui, L., Hu, H., \& Shields, J. (2014). What governs directors' monitoring behavior in China? The influence of director social identification, learning goal orientation, and avoidance orientation. [Article]. Asia Pacific Journal of Management, 31(4), 899-924.

Chatzkel, J., \& Ng, A. W. (2013). The Emergence of Contemporary Chinese Enterprise: The Heterogeneity of National Culture, Corporate Controls and Integration Approaches in M\&As. [Article]. Thunderbird International Business Review, 55(5), 593-608.

CHEN, G., FIRTH, M., GAO, D. N. \& RUI, O. M. (2006). Ownership structure, corporate governance, and fraud: Evidence from China. Journal of Corporate Finance, 12, 424-448.

Chen, G., Firth, M., \& Xu, L. (2009). Does the type of ownership control matter? Evidence from China's listed companies. Journal of Banking \& Finance, 33, 171-181.

CHEUNG, Y.-L., THOMAS CONNELLY, J., LIMPAPHAYOM, P. \& ZHOU, L. (2007). Do Investors Really Value Corporate Governance? Evidence from the Hong Kong Market. Journal of International Financial Management \& Accounting, 18, 86-122.

COFFEE JR, J. C. (2002). Racing towards the top? The impact of cross-listing and stock market competition on international corporate governance. Columbia Law Review, 102, 1757.

Daily, C. M., Dalton, D. R., \& Cannella Jr, A. A. (2003). Corporate govenance: Decades of dialogue and data. [Article]. Academy of Management Review, 28(3), 371-382.

Davis, J. H., Schoorman, F. D., \& Donaldson, L. (1997). Toward a stewardship theory of management. Academy of Management Review, 22, 20-47.

DePamphilis, D. (2010). Mergers, acquisitions, and other restructuring activities (5th ed.). San Diego, Califirnia: Acedemic Press.

Dharwadkar, B., George, G., \& Brandes, P. (2000). Privatization in emerging economies: An agency theory perspective. Academy of Management Review, 25(3), 650-669.

DING, Y., NOWAK, E. \& ZHANG, H. (2010). Foreign vs. domestic listing: An entrepreneurial decision. Journal of Business Venturing, 25, 175-191.

This article is protected by copyright. All rights reserved. 
Donaldson, T. (2012). The epistemic fault line in corproate governance. Academy of Management Review, 37(2), 256-271.

du Plessis, J. J., Hargovan, A., \& Bagaric, M. (2011). Principles of contemporary corporate governance (2nd ed.). Sydney: Cambridge University Press.

Du, Y., Deloof, M., \& Jorissen, A. (2011). Active Boards of Directors in Foreign Subsidiaries. [Article]. Corporate Governance: An International Review, 19(2), 153-168.

Du, Y., Deloof, M., \& Jorissen, A. (2015). The Roles of Subsidiary Boards in Multinational Enterprises. [Article]. Journal of International Management, 21(3), 169-181.

Eisenhardt, K. M. (1989). Agency Theory: An Assessment and Review. [Article]. Academy of Management Review, 14(1), 57-74.

Filatotchev, I., Jackson, G., \& Nakajima, C. (2013). Corporate governance and national institutions: A review and emerging research agenda. Asia Pacific Journal of Management, 30(4), 965-986.

Filatotchev, I., \& Wright, M. (2011). Agency Perspectives on Corporate Governance of Multinational Enterprises. Journal of Management Studies, 48(2), 471-486.

Flyvbjerg, B. (2006). Five Misunderstandings About Case-Study Research. Qualitative Inquiry, 12(2), 219-245.

Foreign Investment Review Board. (2014). Annual Report 2012-13. Retrieved 1/12, 2014, from http://www.firb.gov.au/content/Publications/AnnualReports/2012-2013/ downloads/FIRBAnnual-Report-2012-13.pdf

Friedland, R., \& Alford, R. R. (1991). Bring society back in: Symbols, practices and institutional contradiction. In W. W. Powell \& P. J. DiMaggio (Eds.), The new institutionalism in organizational analysis (pp. 232-263). Chicago: The University of Chicago Press.

Galvin, P. (2014). A new vision for the Journal of Management \& Organization: The role of context. Journal of Management and Organization, 20(1), 1-5.

Garg, S. A. M. (2013). Venture boards: Distinctive monitoring and implications for firm performance. Academy of Management Review, 38(1), 90-108.

Gifford, B., Kestler, A., \& Anand, S. (2010). Building local legitimacy into corporate social responsibility: Gold mining firms in developing nations. Journal of World Business, 45(3), 304-311.

Globerman, S., Peng, M., \& Shapiro, D. (2011). Corporate governance and Asian companies. Asia Pacific Journal of Management, 28(1), 1-14.

Hill, J. G. (2010). The Rising Tension between Shareholder and Director Power in the Common Law World. [Article]. Corporate Governance: An International Review, 18(4), 344-359.

Hillman, A. J., \& Dalziel, T. (2003). Board of directors and firm performance: Integrating agency and resource depedence perspectives. Academy of Management Review, 28(3), 383-396.

Hofstede, G. (2001). Culture's Consequences: Comparing Values, Behaviors, Institutions, and Organizations Across Nations (2nd ed.). Thousand Oaks CA: Sage Publications.

Hu, H. W., \& Cui, L. (2014). Outward foreign direct investment of publicly listed firms from China: A corporate governance perspective. [Article]. International Business Review, 23(4), 750-760.

Hu, H. W., \& Tam, O. (2012). Independent directors in China and India: A comparative assessment. Company and Securities Law Journal, 30, 453-470.

Huang, X., \& Austin, I. (2011). Chinese investment in Australia: Unique insights from the mining industry. London: Palgrave.

Huang, Y. (2001). China's last steps across the river : Enterprise and banking reforms. 
Jeffers, E. (2005). Corporate governance: Toward converging models? [Article]. Global Finance Journal, 16(2), 221-232.

Jensen, M. C., \& Werner, J. B. (1988). The distribution of power among corporate managers, shareholders, and directors. Journal of Financial Economics, 20, 3-24.

Johnson, J. L., Ellstrand, A. E., \& Daily, C. M. (1996). Boards of Directors: A Review and Research Agenda. [Article]. Journal of Management, 22(3), 409.

Joseph, J., Ocasio, W., \& McDonnell, M.-H. (2014). The structural elaboration of board independence: executive power, institutional logics, and the adoption of CEO-only board structure in U.S. corporate governance. Academy of Management Journal, 57(6), 1834-1858.

Kang, Y., Shi, L., \& Brown, E. D. (2008). Chinese corporate governance: History and institutional framework. Retrieved 1/5, 2013, from http://www.rand.org/pubs/technical_reports/TR618.html

Kiel, G. C., \& Nicholson, G. J. (2005). Evaluating Boards and Directors. [Article]. Corporate Governance: An International Review, 13(5), 613-631.

Kostova, T., Marano, V., \& Tallman, S. (2016). Headquarters-subsidiary relationships in MNCs: Fifty years of evolving research. [Article]. Journal of World Business, 51(1), 176-184.

Kostova, T., \& Zaheer, S. (1999). Organizational legitimacy under conditions of complexity: The case of the multinational enterprise. Academy of Management. The Academy of Management Review, 24(1), 64-81.

Krause, R., Semadeni, M., \& Cannella, A. A. (2013). External COO/presidents as expert directors: A new look at the service role of boards. Strategic Management Journal, 34(13), 1628-1641.

Kumar, P., \& Zattoni, A. (2013). Corporate Governance, Board of Directors, and Firm Performance. Corporate Governance: An International Review, 21(4), 311-313.

Kumar, P., \& Zattoni, A. (2015). In Search of a Greater Pluralism of Theories and Methods in Governance Research. Corporate Governance: An International Review, pp. 1-2.

Lazonick, W., \& O'Sullivan, M. (2000). Maximizing shareholder value: a new ideology for corporate governance. Economy and Society, 29(1), 13-35.

Lee, P. (2002). Not Badly Paid But Paid Badly. Corporate Governance: An International Review, 10(2), 69-74.

Liao, J., Young, M. R., \& Sun, W. (2009). Independent Directors' Characteristics and Performance: Evidence from China. Retrieved 1/10, 2013, from http://papers.ssrn.com/sol3/papers.cfm?abstract id=1489088

Liu, Q. (2006). Corporate Governance in China: Current Practices, Economic Effects and Institutional Determinants. CESifo Economic Studies, 52(2), 415-453.

Martin, G., Farndale, E., Paauwe, J., \& Stiles, P. G. (2016). Corporate governance and strategic human resource management: Four archetypes and proposals for a new approach to corporate sustainability. European Management Journal, 34(1), 22-35.

Melkumov, D. (2009). Institutional background as a determinant of boards of directors' internal and external roles: The case of Russia. Journal of World Business, 44(1), 94-103.

Meyer, J. W., \& Rowan, B. (1977). Institutionalised organisation: Formal structure as myth and ceremony. Americal Journal of Sociology, 83(2), 340-363.

Ministry of Commerce (Producer). (2015) 2014 Statistical bulletin of China's outward foreign direct investment.

Monks, R. A. G., \& Minnow, N. (2008). Corporate Governance (4th ed.): John Wiley \& Sons, Ltd. 
Ntongho, R. A. (2016). Culture and corporate governance convergence. International Journal of Law \& Management, 58(5), 523-544.

Ouchi, W. G. (1980). Market, Bureaucracies, and Clan. Administrative Science Quarterly, 25(March), 129-141.

Peltokorpi, V., \& Vaara, E. (2014). Knowledge transfer in multinational corporations: Productive and counterproductive effects of language-sensitive recruitment. Journal of International Business Studies, 45(5), 600-622.

Pfeffer, J., \& Salancik, G. R. (1978). The External Control of Organisations: A Resource Dependence Perspective. New York: Harper \& Row, Publishers.

Renders, A., \& Gaeremynck, A. (2012). Corporate Governance, Principal-Principal Agency Conflicts, and Firm Value in European Listed Companies. Corporate Governance: An International Review, 20(2), 125-143.

Roche, J. (2006). Corporate Governance in Asia. New York: Routledge.

Rowley, C., \& Warner, M. (2013). Strategic challenges and issues for Chinese managers and management in the global economy: conclusions. Asia Pacific Business Review, 19(4), 617624.

SAUDAGARAN, S. M. (1988). AN EMPIRICAL STUDY OF SELECTED FACTORS INFLUENCING THE DECISION TO LIST ON FOREIGN STOCK EXCHANGES. Journal of International Business Studies, 19, 101-127.

Stephensen, P. R. (1936). The Foundations of Culture in Australia. Gordon (N.S.W.): W. J. Miles, .

SUN, L. \& TOBIN, D. (2005). International Listing as a Mechanism of Commitment to More Credible Corporate Governance Practices: the case of the Bank of China (Hong Kong). Corporate Governance: An International Review, 13, 81-91.

SUN, Q., TONG, W. H. S. \& WU, Y. (2013). Overseas listing as a policy tool: Evidence from China's Hshares. Journal of Banking \& Finance, 37, 1460-1474.

Sun, S. L., Zhang, Y., \& Chen, Z. (2013). The Challenges of Chinese Outward Investment in Developed Countries: The Case of CITIC Pacific's Sino Iron Project in Australia. Thunderbird International Business Review, 55(3), 313-322.

Tam, O. K. (2002). Ethical Issues in the Evolution of Corporate Governance in China. Journal of Business Ethics, 37(3), 303-320.

Tam, O. K., \& Yu, P. (2011). China's corporate governance development. In C. Mallin (Ed.), Handbook on international corporate governance (pp. 221-246). Cheltenham, UK and Northampton, USA: Edward Elgar.

Tan, J., Li, M., Li, W., Zheng, H., Wu, J., \& Liang, Y. (2007). An analysis of the characteristics of Chinese listed companies' independent director system. Frontiers of Business Reseach in China, 1(3), 456-481.

Tenev, S., \& Zhang, C. (2002). Corporate governance and enterprise reform in China: Buidling the institutions of modern markets. Washington D.C.: World Bank and International Finance Corporation.

Thornton, P., \& Ocasio, W. (1999). Institutional logics and the historical contingency of power in organizations: Executive succession in the higher education publishing industry, 1958-1990. The American Journal of Sociology, 105(3), 801-843.

Thornton, P., \& Ocasio, W. (2008). Institutional logics. In R. Greenwood, C. Oliver, K. Sahlin \& R. Suddaby (Eds.), The SAGE handbook of organizational institutionalism (pp. 99-129). London: Sage Publications.

This article is protected by copyright. All rights reserved. 
Thornton, P., Ocasio, W., \& Lounsbury, M. (2012). The institutional logics perspective: A new approach to culture, structure, and process. Oxford: Oxford University Press.

Tihanyi, L., Graffin, S., \& George, G. (2014). Rethinking governance in management reserach. [Article]. Academy of Management Journal, 57(6), 1535-1543.

Tsui, A. S. (2007). From homogenization to pluralism: international management research in the academy and beyond. Academy of Management Journal, 50(6), 1353-1364.

UNCTAD. (2010). World investment report. New York and Geneva: UN.

UNCTAD. (2015). World investment report. New York and Geneva: UN.

Van den Berghe, L. A. A., \& Levrau, A. (2004). Evaluating Boards of Directors: what constitutes a good corporate board? Corporate Governance: An International Review, 12(4), 461-478.

Waring, P. (2008). Rethinking directors' duties in changing global markets. [Article]. Corporate Governance: The International Journal of Effective Board Performance, 8(2), 153-164.

Welch, D. E., \& Welch, L. S. (2008). The Importance of Language in International Knowledge Transfer. Management International Review (MIR), 48(3), 339-360.

Westphal, J. D. (1999). Collaboration in the boardroom: Behavioral and performance consrquences of CEO-board social tie. Academy of Management Journal, 42(1), 7-24.

Williams, B., Bingham, S., \& Shimeld, S. (2015). Corporate governance, the GFC and independent directors. Managerial Auditing Journal, 30(4/5), 324-346.

Yang, J., Chi, J., \& Young, M. (2011). A review of corporate governance in China. Asian Pacific Economic Literature, 25(1), 15-28.

Yin, R. K. (2014). Case study research : design and methods (Fifth edition. ed.): SAGE Publication.

Yoo, J. W., \& Kim, K. (2012). Board competence and the top management team's external ties for performance. Journal of Management and Organization, 18(2), 142-158.

Young, M. N., Ahlstrom, D., Bruton, G. F., \& Chan, E. S. (2001). The Resource Dependence, Service and Control Functions of Boards of Directors in Hong Kong and Taiwanese Firms. Asia Pacific Journal of Management, 18(2), 223.

Young, M. N., Peng, M. W., Ahlstrom, D., Bruton, G. D., \& Jiang, Y. (2008). Corporate Governance in Emerging Economies: A Review of the Principal-Principal Perspective. Journal of Management Studies, 45(1), 196-220.

Zahra, S. A., \& Pearce II, J. A. (1989). Boards of directors and coproate financial performance: A review and integrative model. Journal of Management, 15(2), 291-334.

Zattoni, A., \& Van Ees, H. (2012). How to Contribute to the Development of a Global Understanding of Corporate Governance? Reflections from Submitted and Published Articles in CGIR. Corporate Governance: An International Review, 20(1), 106-118.

This article is protected by copyright. All rights reserved. 
Table 1 The scores of national culture dimensions of Australia, the UK, and China

\begin{tabular}{|l|c|c|c|}
\hline Culture dimensions & Australia & UK & China \\
\hline Power difference & 36 & 35 & 80 \\
\hline Individualism & 90 & 89 & 20 \\
\hline Masculinity & 61 & 66 & 66 \\
\hline Uncertainty avoidance & 51 & 35 & 30 \\
\hline Long-term orientation & 21 & 51 & 87 \\
\hline
\end{tabular}

Source: Hofstede (2001)

Table 2 The characteristics of the parent companies and their Australian subsidiary

\begin{tabular}{|c|c|c|}
\hline Company & Parent company's operations & $\begin{array}{l}\text { The industry of } \\
\text { subsidiary's operation }\end{array}$ \\
\hline S1 & $\begin{array}{l}\text { A large Chinese SOE coal mining company. Part of the } \\
\text { company is listed in the Hong Kong Stock Exchange }\end{array}$ & Coal mining \\
\hline S2 & $\begin{array}{l}\text { A large Chinese privately-owned steel company, but has no } \\
\text { operations in mining in China. The controlled firm is a small } \\
\text { supplier of iron ore to the parent company. }\end{array}$ & Iron ore \\
\hline S3 & $\begin{array}{l}\text { A large private conglomerate, but has no operations in mining. } \\
\text { The controlled firm is not a supplier to the parent company. }\end{array}$ & Non-ferrous \\
\hline S4 & A large Chinese SOE gold company. & Gold \\
\hline S5 & $\begin{array}{l}\text { A large Chinese SOE-controlled gold company listed in the } \\
\text { Hong Kong Stock Exchange. }\end{array}$ & Gold \\
\hline S6 & A large Chinese SOE-controlled gold company. & Gold and copper \\
\hline S7 & $\begin{array}{l}\text { A large Chinese SOE nuclear power company. The controlled } \\
\text { subsidiary could be a supplier of raw materials to its parent } \\
\text { company. }\end{array}$ & Uranium \\
\hline S8 & A large Chinese SOE non-ferrous company. & Non-ferrous \\
\hline
\end{tabular}

This article is protected by copyright. All rights reserved. 
Table 3 The board composition and characteristics of the Chinese-controlled companies

\begin{tabular}{|c|c|c|c|c|c|c|c|}
\hline Company & $\begin{array}{l}\text { Chinese } \\
\text { Ownership } \\
\text { (\%) }\end{array}$ & $\begin{array}{l}\text { Total } \\
\text { number of } \\
\text { directors }\end{array}$ & $\begin{array}{l}\text { Number of } \\
\text { insider } \\
\text { directors }\end{array}$ & $\begin{array}{l}\text { Number (\%) of } \\
\text { independent } \\
\text { directors }\end{array}$ & $\begin{array}{l}\text { Chairman } \\
\text { of the } \\
\text { board }\end{array}$ & $\begin{array}{l}\text { Chinese } \\
\text { executive } \\
\text { director }\end{array}$ & $\begin{array}{l}\text { CEO } \\
\text { (A or } \\
\text { C) }\end{array}$ \\
\hline S1 & 78 & 11 & 6 & 5 & $\begin{array}{l}\text { Chinese, } \\
\text { insider * }\end{array}$ & 2 & $A$ \\
\hline S2 & 46 & 7 & 2 & 4 & $\begin{array}{l}\text { Australian, } \\
\text { Chinese } \\
\text { Origin }\end{array}$ & 1 & $C$ \\
\hline S3 & 53.8 & 6 & 3 & 3 & $\begin{array}{l}\text { Chinese, } \\
\text { insider }\end{array}$ & 1 & A \\
\hline S4 & 51 & 4 & 3 & 0 & $\begin{array}{l}\text { Chinese, } \\
\text { insider * }\end{array}$ & 1 & C \\
\hline S5 & 89 & 4 & 1 & 3 & $\begin{array}{l}\text { Chinese, } \\
\text { insider }\end{array}$ & 0 & $C^{\wedge}$ \\
\hline S6 & 53.37 & 6 & 3 & 1 & $\begin{array}{l}\text { Chinese, } \\
\text { insider }\end{array}$ & 1 & A \\
\hline S7 & 60.56 & 7 & 4 & 3 & $\begin{array}{l}\text { Chinese, } \\
\text { insider * }\end{array}$ & 1 & $C$ \\
\hline S8 & 63.4 & 3 & 2 & 0 & $\begin{array}{l}\text { Chinese, } \\
\text { insider * }\end{array}$ & 1 & $C$ \\
\hline & & 48 & 24 & & & & \\
\hline
\end{tabular}

Note: * - President of the Chinese parent company; ^ Chinese origin

This article is protected by copyright. All rights reserved. 
Table 4 The experience and functional background of insider and independent directors and the number of the board meeting

\begin{tabular}{|c|c|c|c|c|c|}
\hline Company & $\begin{array}{l}\text { The business relationship } \\
\text { between the parent } \\
\text { company and subsidiary }\end{array}$ & $\begin{array}{l}\text { Insider director's experience and } \\
\text { areas of expertise }\end{array}$ & $\begin{array}{l}\text { Independent director's experience and } \\
\text { areas of expertise }\end{array}$ & $\begin{array}{l}\text { Stage of } \\
\text { operations }\end{array}$ & $\begin{array}{l}\text { Number } \\
\text { of board } \\
\text { meeting }\end{array}$ \\
\hline S1 & $\begin{array}{l}\text { Market expansion as both } \\
\text { companies are operating in } \\
\text { the same industry }\end{array}$ & $\begin{array}{l}\text { Management, engineering (3), } \\
\text { accounting \& finance ( } 2 \text { ) }\end{array}$ & $\begin{array}{l}\text { Financing, government relations, mining } \\
\text { operations and management, railway } \\
\text { transportation and occupational health } \\
\text { and safety, Auditing \& risk management }\end{array}$ & Production & 6 \\
\hline S2 & $\begin{array}{l}\text { Vertical integration as the } \\
\text { subsidiary is a small } \\
\text { supplier of iron ore to its } \\
\text { parent company }\end{array}$ & Project development, legal & $\begin{array}{l}\text { Metallurgy, mining services, and legal } \\
\text { services }\end{array}$ & Production & 10 \\
\hline S3 & $\begin{array}{l}\text { Diversification as the } \\
\text { parent and the subsidiary } \\
\text { do not operate in the same } \\
\text { industry, nor in the same } \\
\text { value network }\end{array}$ & Accounting, Management, N/A (1) & $\begin{array}{l}\text { Geology, mineral exploration, and } \\
\text { business development \& financing }\end{array}$ & $\begin{array}{l}\text { Mine in } \\
\text { cares, } \\
\text { exploration }\end{array}$ & 13 \\
\hline S4 & Market expansion & $\begin{array}{l}\text { mining and geology, Mining } \\
\text { engineering, Accounting \& finance }\end{array}$ & Geology \& exploration & $\begin{array}{l}\text { Mine in } \\
\text { cares, } \\
\text { exploration }\end{array}$ & 4 \\
\hline S5 & Market expansion & geology \& management & $\begin{array}{l}\text { Geology, accounting, and business } \\
\text { development }\end{array}$ & Production & 15 \\
\hline S6 & Market expansion & $\begin{array}{l}\text { Mining \& management, Business } \\
\text { administration (financial risk } \\
\text { management), Marketing \& } \\
\text { procurement }\end{array}$ & $\begin{array}{l}\text { A professional company Director, legal } \\
\text { services }\end{array}$ & Production & 10 \\
\hline S7 & Vertical integration & $\begin{array}{l}\text { Geology \& management, geology \& } \\
\text { exploration, engineering. }\end{array}$ & Geology, mining engineering & Exploration & 2 \\
\hline S8 & Market expansion & $\begin{array}{l}\text { Mining engineering, international } \\
\text { business }\end{array}$ & Geology & Exploration & 3 \\
\hline
\end{tabular}

This article is protected by copyright. All rights reserved. 


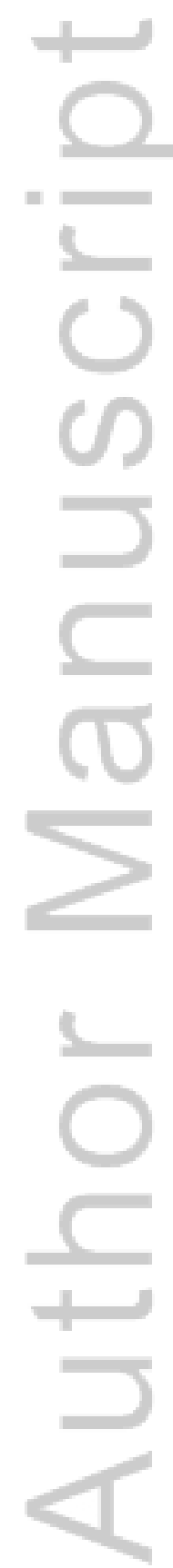

This article is protected by copyright. All rights reserved. 
Table 5 The interlocks of independent directors in Chinese -controlled subsidiaries

\begin{tabular}{|l|l|l|l|l|}
\hline Company & $\begin{array}{l}\text { Number of } \\
\text { independent } \\
\text { directors out of } \\
\text { total number of } \\
\text { directors }\end{array}$ & $\begin{array}{l}\text { Number of } \\
\text { interlocking } \\
\text { independent } \\
\text { directors }\end{array}$ & Interlocking sectors & $\begin{array}{l}\text { International } \\
\text { interlocks }\end{array}$ \\
\hline S1 & $5 / 11$ & 5 & $\begin{array}{l}\text { Mining, transport, investment, } \\
\text { public sector (OSH) }\end{array}$ & No \\
\hline S2 & $4 / 7$ & 2 & $\begin{array}{l}\text { Mining only for two independent } \\
\text { directors }\end{array}$ & No \\
\hline S3 & $3 / 6$ & 3 & $\begin{array}{l}\text { Mining only for three } \\
\text { independent directors }\end{array}$ & No \\
\hline S4 & $0 / 4$ & 0 & N/A & \\
\hline S5 & $3 / 4$ & 0 & N/A & No \\
\hline S6 & $1 / 6$ & 1 & Mining & No \\
\hline S7 & $3 / 7$ & 2 & Mining, engineering services & \\
\hline S8 & $0 / 3$ & 0 & N/A & \\
\hline Total & $19 / 48$ & 13 & & \\
\hline
\end{tabular}

This article is protected by copyright. All rights reserved. 
Table 6 Board functions. Key mechanisms and rationales of Chinese-controlled firms in Australia

\begin{tabular}{|c|c|c|c|}
\hline Board function & $\begin{array}{c}\text { Chinese } \\
\text { controlled firms } \\
\text { in Australia }\end{array}$ & Key mechanisms & Rationale \\
\hline $\begin{array}{l}\text { Control and } \\
\text { monitoring }\end{array}$ & $\begin{array}{l}\text { Primary: The } \\
\text { most important } \\
\text { function } \\
\text { performed by the } \\
\text { board }\end{array}$ & $\begin{array}{l}\text { - A majority of insider directors } \\
\text { - A majority of insider directors } \\
\text { and independent directors of } \\
\text { Chinese origin } \\
\text { - Insider chairperson of the } \\
\text { board } \\
\text { - Insider CEO } \\
\text { - Insider executive director } \\
\text { - Frequent board meetings }\end{array}$ & $\begin{array}{l}\text { - Institutional logic } \\
\text { of corporate } \\
\text { control in China; } \\
\text { - } \quad \text { Trust; } \\
\text { - } \quad \text { Language; } \\
\text { - } \quad \text { Cultural } \\
\text { understanding }\end{array}$ \\
\hline Service & Secondary & $\begin{array}{l}\text { - Parent company collectively } \\
\text { - Independent directors } \\
\text { complementary }\end{array}$ & $\begin{array}{l}\text { - Lack of expertise } \\
\text { and experience in } \\
\text { host country; } \\
\text { Trade-off for } \\
\text { control; } \\
\text { Weak perception of } \\
\text { the importance of } \\
\text { services by the } \\
\text { board to CEO in } \\
\text { China }\end{array}$ \\
\hline $\begin{array}{l}\text { Resource } \\
\text { dependence }\end{array}$ & Tertiary & $\begin{array}{l}\text { - } \quad \text { Business network } \\
\text { - } \quad \text { Social capitals and legitimacy } \\
\text { - } \quad \text { Parent company for financing }\end{array}$ & $\begin{array}{l}\text { Parent company's } \\
\text { capability to get } \\
\text { financing support } \\
\text { from Chinese } \\
\text { government and } \\
\text { banks } \\
\text { - Lack of business } \\
\text { network in host } \\
\text { country } \\
\text { - Lack of legitimacy }\end{array}$ \\
\hline
\end{tabular}

This article is protected by copyright. All rights reserved. 


\section{University Library}

\section{- M M N E R VA A gateway to Melbourne's research publications}

Minerva Access is the Institutional Repository of The University of Melbourne

Author/s:

Huang, X;Staples, W

Title:

Do Chinese corporations take their governance practices abroad? Evidence from Chinese mining subsidiaries in Australia

Date:

2018-07-01

Citation:

Huang, X. \& Staples, W. (2018). Do Chinese corporations take their governance practices abroad? Evidence from Chinese mining subsidiaries in Australia. THUNDERBIRD INTERNATIONAL BUSINESS REVIEW, 60 (4), pp.619-632. https://doi.org/10.1002/tie.21918.

Persistent Link:

http://hdl.handle.net/11343/293121 